\title{
Influence of Temperature, Roughness and Washer Shape on Crevice Corrosion for 254 SMO Alloy
}

\author{
Sanaa T. Arab ${ }^{1}$, Khadijah M. Emran ${ }^{2}$, Huda M. Alghamdi ${ }^{1}$, Mohammed I. Abdulsalam ${ }^{3}$ \\ ${ }^{1}$ Department of Physical Chemistry, King Abdul-Aziz University, Jeddah, Saudi Arabia \\ ${ }^{2}$ Chemistry Department, Faculty of Science, Taibah University, Al-Medina Al-Monawara, Saudi Arabia \\ ${ }^{3}$ Department of Chemical and Materials Engineering, King Abdul-Aziz University, Jeddah, Saudi Arabia \\ Correspondence: Khadijah M. Emran, Chemistry Department, Faculty of Science, Taibah University, Saudi \\ Arabia. Tel: +966-50-435-5039. E-mail: kabdalsamad@taibahu.edu.sa
}

Received: August10, 2015

Accepted: August 24, 2015 Online Published: September 25, 2015

doi:10.5539/ijc.v7n2p106

URL: http://dx.doi.org/10.5539/ijc.v7n2p106

\begin{abstract}
Effect of temperature, roughness and washer shape on 254 SMO alloy was applied to study the susceptibility of alloy's crevice corrosion. XPS measurements have been carried out to detect and define the products which formed on the surface of $254 \mathrm{SMO}$ in $22 \% \mathrm{NaCl}$ at $30^{\circ} \mathrm{C}$ at applied potential $600 \mathrm{mV}_{\mathrm{SCE}}$. The formation of $\mathrm{Fe}, \mathrm{Cr}$ and Mo compounds which play a great role to protect the alloy was found.
\end{abstract}

Keywords: crevice corrosion, 254 SMO, temperature, roughness, washer shape effect, potentiostatic, XPS

\section{Introduction}

254 SMO is considered to be a very high austenitic stainless steel. It was originally developed for use in seawater and other aggressive chloride-bearing environments. Many parameters, such as temperature and crevice geometry, were used to obtain their effect on crevice corrosion.

An increase in temperature tend to stimulate corrosive attack by increasing the rate of electrochemical reactions(Roberge 2000). For stainless steels and other alloys that are prone to pitting and crevice corrosion, an increase in temperature tends to facilitate initiation of these types of attack(Roberge 2000). Many parameters that influence corrosion can vary with temperature: dissolved oxygen solubility, solution properties (e.g. viscosity and ion mobility), ferrous oxidation rate and thermodynamic properties of iron scale (leading to formation of different phases or compounds) (McNeill 2002).

Crevice geometry is one of the important factors in crevice corrosion susceptibility. The two dimensions that characterize a crevice, the gap and the depth or length exert a great deal of control on the initiation and propagation of crevice corrosion, in agreement with that in the other studies(Kelly RG 2003). The current flow from the crevice to the outer surface is partially supported by the inward migration on anions such as $\mathrm{Cl}^{-}$, which further lowers the $p \mathrm{H}$. In these respects, the mechanisms of the crevice and pitting corrosion are similar. In view of this sequence, the crevice geometry parameters of gap width and depth become important(Ahmad 2006). The corrosion rate within the crevice increased as the crevice dimension decreases(Palmer 2008).

In this study, the effect temperature, roughness and washer shape on the crevice corrosion of 254 SMO alloy was tested. XPS technique was used to identifying constituent species of corrosion products.

\section{Experimental}

In this study a rectangular- shaped specimen of $254 \mathrm{SMO}$ alloy with $60 \mathrm{~mm} \times 30 \mathrm{~mm} \times 3 \mathrm{~mm}$ exposed areas and a $7 \mathrm{~mm}$ diameter of a hole in the center was used. The hole in the center was used for the attachment of the multiple crevice test assembly and another smaller hole on the top of the specimen was used for electrical contact using a titanium wire. The sample was finally polished to 1000 silicon carbide paper then it was cleaned and degreased by ultrasound using acetone. The compositions of 254 SMO alloy are listed in Tab. 1. 
Table 1. Chemical compositions (\%wt) of 254 SMO

\begin{tabular}{ccccccccccc}
\hline $\mathbf{C}$ & $\mathbf{C r}$ & $\mathbf{C u}$ & $\mathbf{M n}$ & $\mathbf{M o}$ & $\mathbf{N i}$ & $\mathbf{N}$ & $\mathbf{P}$ & $\mathbf{S i}$ & $\mathbf{S}$ & $\mathbf{F e}$ \\
\hline$\leq 0.020$ & 20 & 0.7 & $\leq 1.00$ & 6.1 & 18 & 0.20 & $\leq 0.030$ & $\leq 0.80$ & $\leq 0.010$ & 53.14
\end{tabular}

A multiple crevice test assembly made of Teflon from Metal Samples Co. Each washer has 20 teeth. A circular disc of $25 \mathrm{~mm}$ diameter was cleaned and degreased by ultrasound using double distilled water. The multiple crevice washers were bolted to both sides of each specimen using screw and nuts (made of Titanium). The screw bolt was inserted in a plastic tube, Fig. 1, to protect it from the solution.

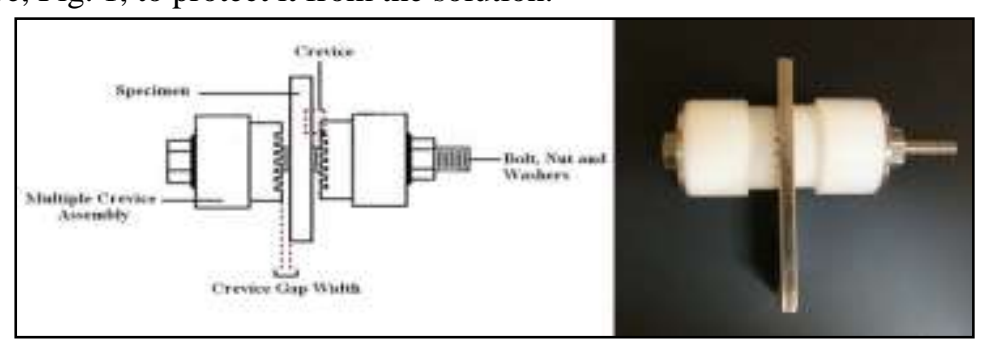

Figure 1. Schematic and photograph of the crevice assembly used in the study

The corrosion cell contains $1000 \mathrm{ml}$ of aerated $22 \% \mathrm{NaCl}$ solution. A carbon electrode and a saturated calomel electrode $(S C E)$ were used as a counter and a reference electrodes respectively. Salt bridge with Luggin capillary was used to connect the reference electrode to the corrosion cell. Test solution was used in the salt bridge. The cell was connected to PC14/750 Gamrypotentiostat for the potentiostatic study. Effect of temperature was tested at $\mathrm{E}_{\text {apply }}=600 \mathrm{mV}_{\mathrm{SCE}}$ at room temperature, $30^{\circ} \mathrm{C}, 40^{\circ} \mathrm{C}$ and $55^{\circ} \mathrm{C}$. SCE was put in the Luggin capillary, not in the direct solution and the value of SCE potential doesn't change in the studied range of temperature. After experiments, SCE impedance was tested using Gamry EIS. Effect of roughness was tested at at $E_{\text {apply }}=400 \mathrm{mV} \mathrm{SCE}_{\mathrm{S}}$ at final polishing 600 and $1200 \mathrm{SiC}$. Effect of washers shape was tested using grooved and flat washers at $\mathrm{E}_{\text {apply }}=$ $400 \mathrm{mV}_{\text {SCE}}$.

Chemical compositions on 254 SMO surface after the study were noticed by XPS using a multi-technique surface analysis system (MAX200, Leybold).

\section{Results and Discussion}

\subsection{Effect of Temperature}

The effect of temperature on crevice corrosion behavior for 254 SMO alloy was studied at four temperatures in $22 \% \mathrm{NaCl}$ at applied potential $600 \mathrm{mV}_{\mathrm{SCE}}$ as shown in Tab. 2. The sample that was tested at room temperature $\left(25^{\circ} \mathrm{C}\right)$ did not show any signs of crevice corrosion after three days. Also, it did not show any corrosion activity through current measurements with time (Figs. 2 and 3). The samples tested at 30, 40 and $55^{\circ} \mathrm{C}$ showed crevice corrosion attacks as shown in Fig.2. It is appeared that the crevice corrosion sets increased with temperature increasing.

Table 2. Crevice Corrosion Susceptibility Results for $254 \mathrm{SMO}$ at Different Temperatures in $22 \% \mathrm{NaCl}$ at $E_{a p p l}=$ $600 m V_{S C E}$ at Torque Value $=2.5 \mathrm{in} l b f$

\begin{tabular}{cccc}
\hline Temp. $\left({ }^{\circ} \mathrm{C}\right)$ & Time $(k s)$ & $\begin{array}{c}\text { Corrosion } \\
\text { attack }\end{array}$ & $\begin{array}{c}\text { Induction } \\
\text { period }(k s)\end{array}$ \\
\hline Room temp. $\left(25^{\circ} \mathrm{C}\right)$ & 259.2 & No & - \\
30 & 259.2 & Yes $(12 / 40)$ & 72.13 \\
40 & 259.2 & Yes $(34 / 40)$ & 5.345 \\
55 & 0.420 & Yes $(40 / 40)$ & 0.040 \\
\hline
\end{tabular}




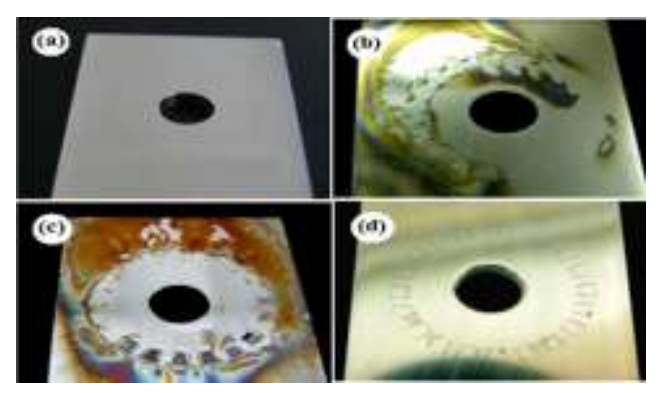

Figure 2. Effect of temperature on crevice corrosion for $254 S M O$ sample in $22 \% \mathrm{NaCl}$ at $E_{a p p l}=600 \mathrm{~m} V_{S C E}$ at torque value $=2.5 \mathrm{in} l b f$
(a) at room temperature $\left(25^{\circ} \mathrm{C}\right)$,
(b) at $30^{\circ} \mathrm{C}$,
(c) at $40^{\circ} \mathrm{C}$,
(d) at $50^{\circ} \mathrm{C}$

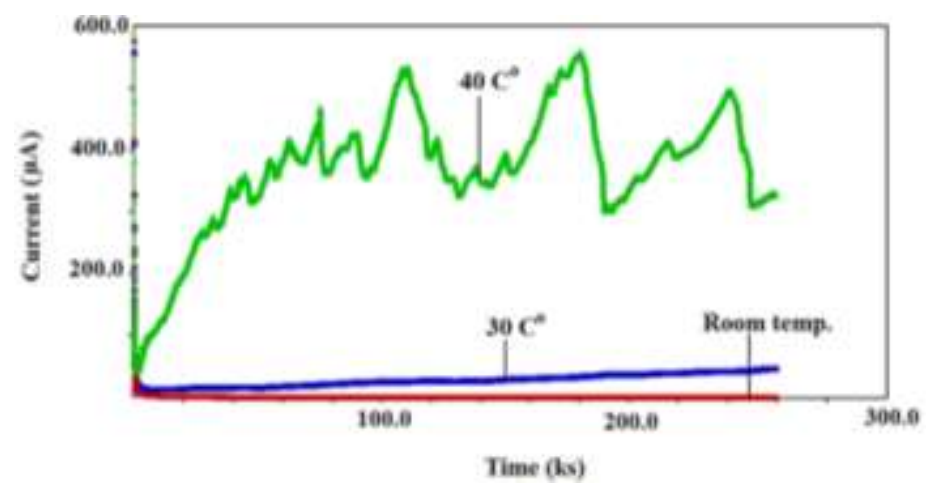

Figure 3. Measured current with time for $254 \mathrm{SMO}$ sample at different temperatures in $22 \% \mathrm{NaCl}$ at $E_{a p p l}=600$ $m V_{S C E}$ at torque value $=2.5$ in $\mathrm{lbf}$

In the test at $30^{\circ} \mathrm{C}$, the current continued to increase gradually in very low rate $(0.1080 \mu \mathrm{A} / \mathrm{ks})$ with time (Fig.3) While at $40^{\circ} \mathrm{C}$, the current increased significantly with time at the beginning of the experiment then a noticeable fluctuation in current value is found which is suggested to be due to a competition between formation and deformation of oxide passive film. Dissolution and re-built of the protective films were continued until the end of the experiment. The fluctuation in current value may be due to the competitive mechanism between passivating species $[\mathrm{MOOH}]_{\mathrm{ads}},[\mathrm{MOMOH}]_{\mathrm{ads}}$ and non-passivating species $[\mathrm{MOH}]_{\mathrm{ads}},[\mathrm{MOMCl}]_{\mathrm{ads}}$, $[\mathrm{MOMOHCl}]_{\text {ads }}$ as suggested by (Pujar et al. 2007).

Figure 4 shows the current resulted from $254 \mathrm{SMO}$ corrosion at $55^{\circ} \mathrm{C}$. The current increased sharply to $\sim 20.5 \mathrm{~mA}$ in 7 minutes only. Comparing test at temperatures $30^{\circ} \mathrm{C}, 40^{\circ} \mathrm{C}$ and $55^{\circ} \mathrm{C}$, the induction period decreased with the temperature increasing as shown in Tab. 2.

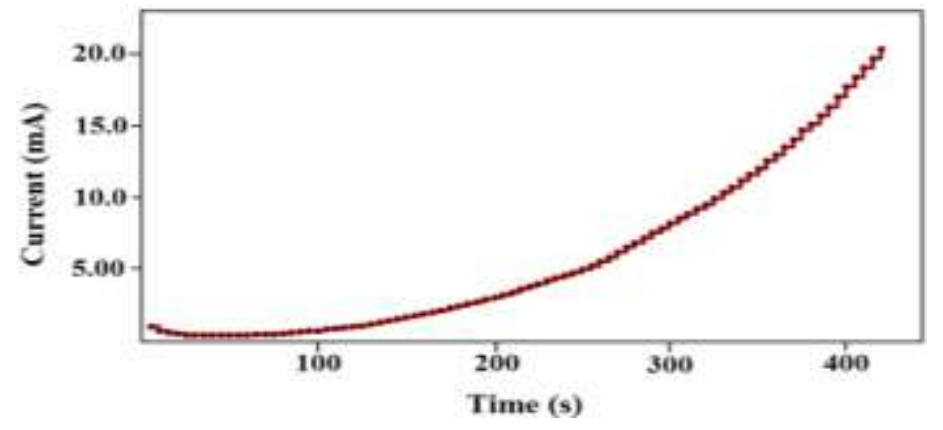

Figure 4. Measured current with time for $254 \mathrm{SMO}$ sample in $22 \% \mathrm{NaCl}$ at $E_{a p p l}=600 \mathrm{mV} V_{S C E}$ at $55^{\circ} \mathrm{C}$ at torque value $=2.5$ in $\mathrm{lbf}$

The possibility of a temperature induced change in the protective properties of the passive film on alloy surface, resulting in a reduction in its resistance to breakdown as temperature is increased. This change can be rationalized by taking two possibilities into consideration. First, the porosity of the passive film often assumed to increase with temperature(Bogaert et al. 1981). The increase in porosity with temperature is supported by the fact 
that $\mathrm{Cl}^{-}$ions have been found to incorporate into the passive film on stainless steel at high temperatures, but not at lower temperatures. Wang et al. (1988) has proved that at higher temperatures, the passive film on stainless steel becomes thicker but more porous, leading it to be much less protected. So, at higher temperatures, weaker the protective property of the passive film is found. Second, the passive film may undergo an intrinsic modification of its chemical composition and/or physical structure resulting, for example, in a variation of the density of vacancies or voids in the oxide film (Roy et al. 1997).

In $\mathrm{NaCl}$ solution, $254 \mathrm{SMO}$ can form the passive film. Once a film is formed, the reaction rate between a metal and its surrounding environment will be lower several orders of magnitude. The passive film, probably with a bilayer structure: an inner layer rich in $\mathrm{Cr}_{2} \mathrm{O}_{3}$ and an outer porous layer abundant with $\mathrm{Cr}(\mathrm{OH})_{3}$ (Marcus and Olefjord 1988)(Olefjord and Wegrelius 1990)(Dong et al. 2011). According to (Qvarfort 1998), the two steps in which a passive film formed in a solution will be, as follows: first chromium-rich passive film dissolves in the solution, and second the chromium inside the stainless steel diffuses to the metal surface and then forms new passive layers. As the temperature rises, the first step is quicker than the second step. So with the temperature increasing, the passive film becomes thinner and leads the film easier to be ruptured. Both possibilities should be considered(Bogaert et al. 1981, Manning \& Duquette 1980).

To define the products of the corrosion, XPS has been carried out to 254 SMO surface after corrosion in $22 \% \mathrm{NaCl}$ at applied potential $=600 \mathrm{mV}_{\mathrm{SCE}}$ as shown in Fig. 5. Iron compounds $\left(\mathrm{Fe}_{2} \mathrm{O}_{3}\right.$ and $\left.\mathrm{FeCl}_{2}\right)$, Chromium compounds $\left(\mathrm{CrCl}_{3}, \mathrm{Cr}_{2} \mathrm{O}_{3}\right.$ and $\left.\mathrm{CrOOH}\right)$, Molybdenum oxide $\left(\mathrm{MoO}_{3}\right)$ and Nickel chloride have been detected by XPS measurement. The nature of passive film of stainless steels is a mixture of metal oxides and oxyhydroxides. It has been suggested that $\mathrm{Mo}^{6+}$ ions are present in the outer layer. They may act as cation selective species in the outer layer producing a bipolar passive film, with the inner layer which contains $\mathrm{Cr}_{2} \mathrm{O}_{3}$ being anion selective. Thus, the inward passage of cations produced by metallic dissolution at the metal/oxide interface is not favored (Clayton, \& Olejford 1995),( McCafferty 2010).

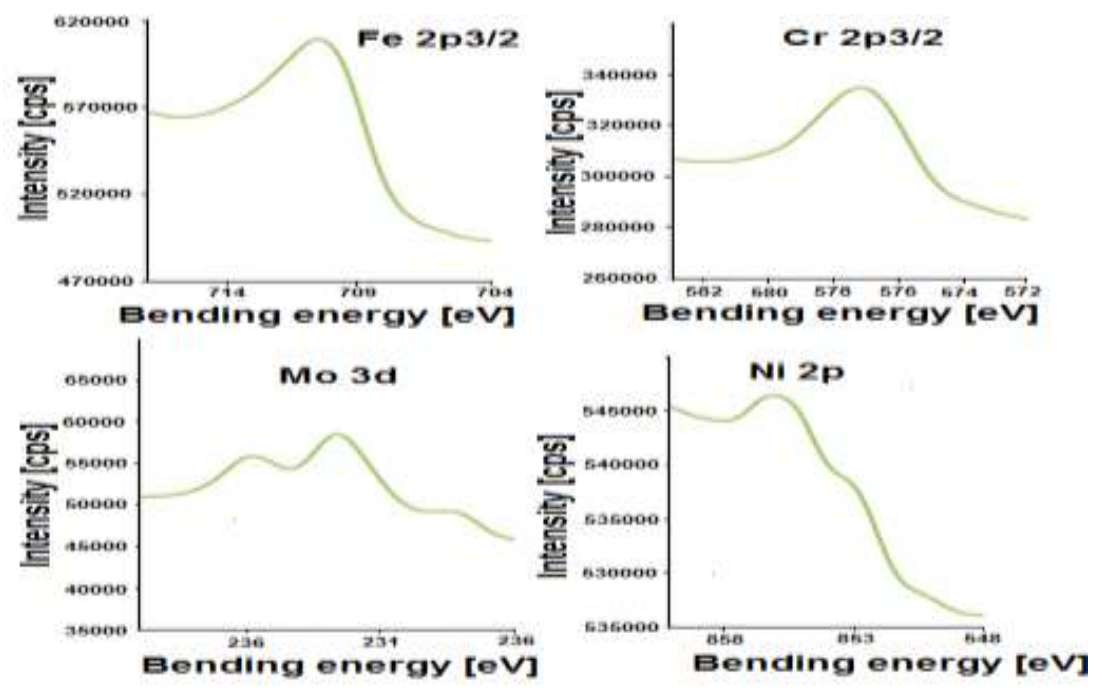

Figure 5. XPS measurement for $\mathrm{Cr}, \mathrm{Fe}, \mathrm{Mo}$ and $\mathrm{Ni}$ on $254 \mathrm{SMO}$ alloy surface after corrosion in $22 \% \mathrm{NaCl}$ at $30^{\circ} \mathrm{C}$ at $600 \mathrm{~m} V_{S C E}$

\subsection{Effect of Surface Roughness}

To study the effect of surface roughness, two tests were performed at same experiment conditions, in $22 \% \mathrm{NaCl}$ at $E_{\text {appl }}=400 \mathrm{~m} V_{S C E}$, but they have different final polishing $(600$ and $1200 \mathrm{SiC})$. It was found that the number of crevice corrosion sets with final polishing $600 \mathrm{SiC}(17 / 40)$ is more than the number of crevice corrosion sets with final polishing $1200 \mathrm{SiC}$ (14/40) as shown in Tab.3 and Fig. 6.

Table 3. Crevice Corrosion Susceptibility Results for $254 \mathrm{SMO}$ at Different Surface Roughness in $22 \% \mathrm{NaCl}$ at $E_{\text {appl }}=400 \mathrm{~m} V_{S C E}$ at $30^{\circ} \mathrm{C}$ at Torque Value $=10 \mathrm{in} \mathrm{lbf}$

\begin{tabular}{cccc}
\hline Time $(k s)$ & Final polishing & Corrosion attack & Induction period $(k s)$ \\
\hline 172.8 & 1200 & Yes $(14 / 40)$ & 2.681 \\
86.40 & 600 & Yes $(17 / 40)$ & 3.888 \\
\hline
\end{tabular}

The current for $254 \mathrm{SMO}$ corrosion at final polishing $600 \mathrm{SiC}$ takes more time to increase than it at final polishing $1200 \mathrm{SiC}$, Tab. 4 , and it increased slightly to values more than it at final polishing $1200 \mathrm{SiC}$ as shown in 
Fig. 7. The corrosion rates for 254 SMO corrosion in the two tests were almost the same $(2.8 \mu \mathrm{A} / \mathrm{ks})$ but the current in test at final polishing $600 \mathrm{SiC}$ continue to increase for longer time.

Table 4. Crevice Corrosion Susceptibility Results for $254 \mathrm{SMO}$ at Different Washer Shape in $22 \% \mathrm{NaCl}$ at $E_{\text {appl }}=$ $400 \mathrm{~m} V_{S C E}$ at $30^{\circ} \mathrm{C}$ at Torque Value $=10.5 \mathrm{in} \mathrm{lbf}$

\begin{tabular}{ccc}
\hline Time $(s)$ & washers & Corrosion attack \\
\hline 172.8 & Grooved washers & Yes $(14 / 40)$ \\
86.40 & Flat washers & Yes \\
\hline
\end{tabular}
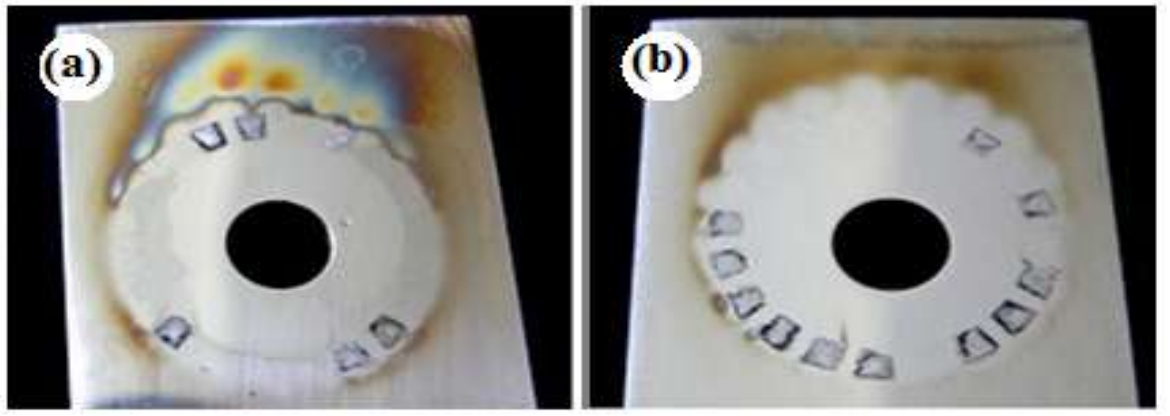

Figure 6. Effect of roughness (final polishing) on crevice corrosion for $254 \mathrm{SMO}$ sample in $22 \% \mathrm{NaCl}$ at $E_{a p p l}=$ $400 \mathrm{~m} V_{S C E}$ at $30^{\circ} \mathrm{C}$ at torque value $=10 \mathrm{in} \mathrm{lbf}$. (a) $1200 \mathrm{SiC}$ paper, (b) $600 \mathrm{SiC}$ paper

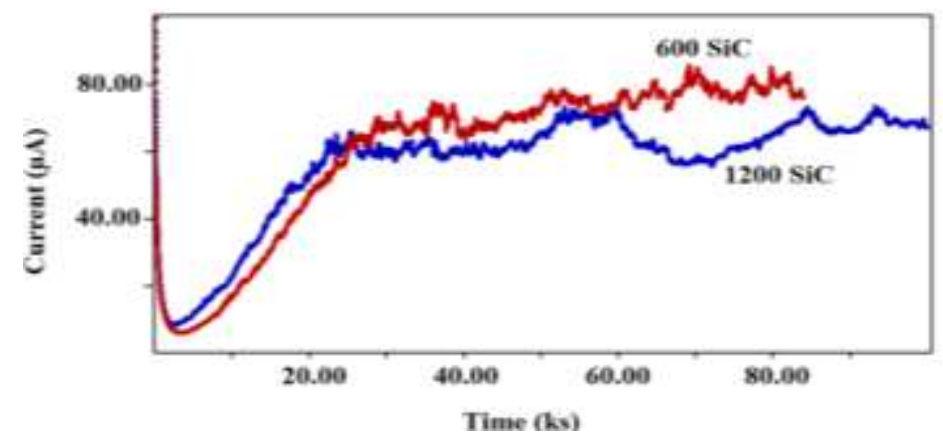

Figure 7. Measured current with time for $254 \mathrm{SMO}$ sample at different final polishing in $22 \% \mathrm{NaCl}$ at $E_{a p p l}=$ $400 \mathrm{mV} V_{S C E}$ at $30^{\circ} \mathrm{C}$ at torque value $=10 \mathrm{in} \mathrm{lbf}$

\subsection{Effect of Washers Shape}

Flat and grooved washers were used for $254 \mathrm{SMO}$ alloy in $22 \% \mathrm{NaCl}$ at $E_{a p p l}=400 \mathrm{mV} V_{S C E}$ as shown in Tab. 4 and Fig. 8. By comparing the results between the test using flat washers and the test using grooved washers, the sample using flat takes more time to start corrosion. The value of current with time, Fig. 9, for 254 SMO sample corrosion in the test using flat washers is lower than it in the test using grooved washers.
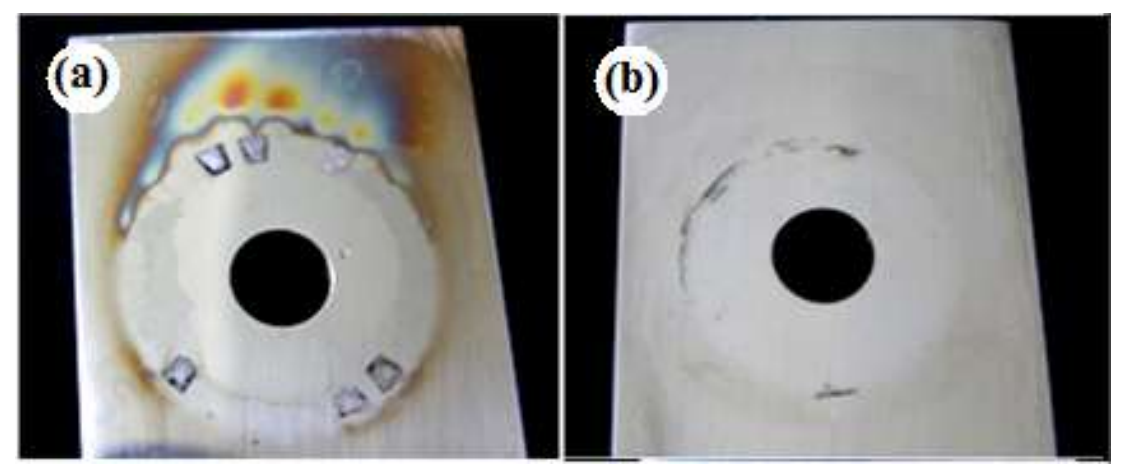

Figure 8. Effect of washers shape on crevice corrosion for $254 \mathrm{SMO}$ sample in $22 \% \mathrm{NaCl}$ at $E_{a p p l}=400 \mathrm{~m} V_{S C E}$ at $30^{\circ} \mathrm{C}$ at torque value $=10 \mathrm{in} \mathrm{lbf}$

(a) Grooved washers, (b) flat washers 


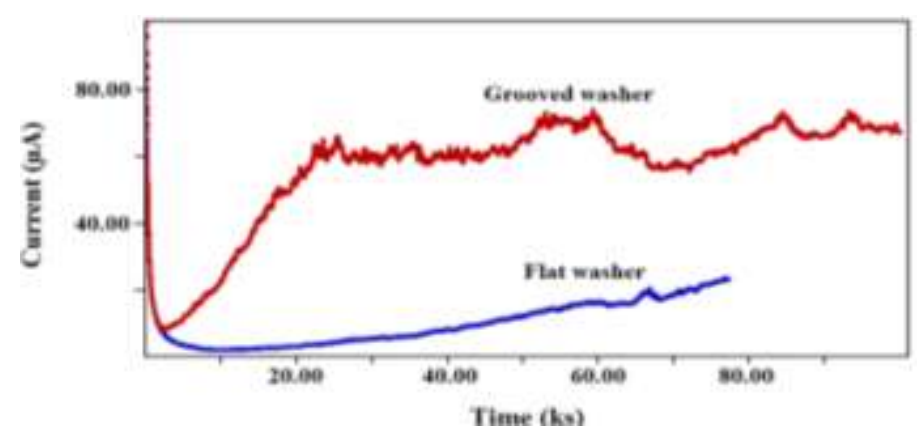

Figure 9. Measured current with time for $254 \mathrm{SMO}$ sample at different washer shapes in $22 \% \mathrm{NaCl}$ at $E_{\text {appl }}=400$ $m V_{S C E}$ at $30^{\circ} \mathrm{C}$ at torque value $=10 \mathrm{in} \mathrm{lbf}$

In the test using grooved washers, there are 40 locations ( 40 crevices) where crevice corrosion can initiate during the exposure time in the test. Each crevice may separately initiate crevice corrosion at different times during the study. If crevice corrosion initiated at one location, then stifled may appear in another location, this behavior may give the zigzag shape in the current-time curve. While in the test using flat washers, a gradual increase and smooth shape are found due to the presence of only one crevice.

The grooved washers have smaller crevice than the flat washers which means that the oxygen depletion and chloride-ion influx increased in grooved washer leading to accelerate the crevice corrosion initiation. (Oldfield et al. 1984)], have shown that the gap dimension of the crevice has a major influence on the development of a critical crevice solution within the crevice and initiation/no initiation in any given crevice.

\section{Conclusion}

1. Increasing temperature leads to increase the number of corrosion sets and decrease the induction period.

2. The effect of polishing on the corrosion results for the sample (from $600 \mathrm{SiC}$ to $1200 \mathrm{SiC}$ ) did not show significant differences in current values but the number of corrosion sets decreases with final polishing increasing.

3. Flat washer has delayed the corrosion initiation comparing with grooved washer.

\section{Acknowledgment}

This work was financially supported by KACST, Saudi Arabia. The authors wish to thank Prof. Hamad A. Al-Turaif.

\section{References}

Ahmad, Z. (2006). Principles_of_Corrosion_Engineering_and. Edited by Butterworth-Heinemann. 1st ed. Elssevier Ltd.

Andrew, C. P., \& Roger, A. K. (2008). Subsea Pipeline Engineering. 2nd ed. Okahoma USA: PennWell Books.

Bogaert, W., Van Haute, A., \& Brabers, M. (1981).Passivity of Austenitic Stainless Steel in High TemperatureHigh Pressure Aqueous Solutions International Congress on Metallic Corrosionn.

Clayton, C. R., \& Olejford, I. (1995). Corrosion Mechanisms in Theory and Practice. Edited by J. Marcus, P., Oudar. New York: Marcel Dekker.

Dong, C., Luo, H., Xiao, K., Sun, T., Liu, Q., \& Li, X. (2011). Effect of Temperature and Cl- Concentration on Pitting of 2205 Duplex Stainless Steel. Journal of Wuhan University of Technology-Mater. Sci. Ed. 26(4), 641.

Oldfield, J. W., Lee, T. S., \& Kain, R. M. (1984). Avoiding Crevice Corrosion of Stainless Steels. Stainless Steel'84, Chalmers University of Technology, 205-216.

Kelly, R. G. (2003). Crevice Corrosion, Corrosion: Fundamentals, Testing, and Protection, ASM Handbook. ASM International. 13A, 242.

Manning, P. E., \& Duquette, J. (1980). The Effect of Temperature $\left(25^{\circ}-289^{\circ} \mathrm{C}\right)$ on Pit Initiation in Single Phase and Duplex 304L Stainless Steels in $100 \mathrm{Ppm} \mathrm{Cl}-$ Solution. Corrosion Science, 20(4), 597-609. http://dx.doi.org/10.1016/0010-938X(80)90074-8 
Marcus, P., \& Olefjord, I. (1988). A Round Robin on Combined Electrochemical and AES/ESCA Characterization of the Passive Films on $\mathrm{Fe} \mathrm{Cr}$ and $\mathrm{Fe} \mathrm{Cr}$ Mo Alloys. Corrosion Science, 28(6), 589-602. http://dx.doi.org/10.1016/0010-938X(88)90026-1

McCafferty, E. (2010). Introduction to Corrosion Science. Edited by E. McCafferty. E. McCaffe. New York: Springer New York. http://dx.doi.org/10.1007/978-1-4419-0455-3_9

McNeill, L. S., \& Edwards, M. (2002). The Importance of Temperature in Assessing Iron Pipe Corrosion in Water Distribution Systems. Environmental Monitoring and Assessmen, 77(3).

Olefjord, I., \& Wegrelius, L. (1990). Surface Analysis of Passive State. Corrosion Science, 31(January), 89-98. http://dx.doi.org/10.1016/0010-938X(90)90095-M

Pujar, M. G., Anita, T., Shaikh, H., Dayal, R. K., \& Khatak, H. S. (2007). Use of Electrochemical Noise (EN) Technique to Study the Effect of Sulfate and Chloride Ions on Passivation and Pitting Corrosion Behavior of 316 Stainless Steel. Journal of Materials Engineering and Performance, 16(4), 494-499. http://dx.doi.org/10.1007/s11665-007-9078-3

Qvarfort, R. (1998). Some Observations Regarding the Influence of Molybdenum on the Pitting Corrosion Resistance of Stainless Steels. Corrosion Science, 40(2-3), $215-223$. http://dx.doi.org/10.1016/S0010-938X(97)00118-2

Roberge, P. R. (2000). Handbook of Corrosion Engineering. Inc.USA: The McGraw-Hill Companies.

Roy, A. K., Fleming, D. L., \& Lum, B. Y. (1997). Fifth International Conference on Nuclear Variables on Localized Corrosion of High-Performance Container Materials.

Wang, J. H., Siu, C. C., \& Szklarska-Smialowska. (1988). Effects of Cl- Concentration and Temperature on Pitting of AISI 304 Stainless Steel. Corrosion, 44, 732-737. http://dx.doi.org/10.5006/1.3584938

\section{Copyrights}

Copyright for this article is retained by the author(s), with first publication rights granted to the journal.

This is an open-access article distributed under the terms and conditions of the Creative Commons Attribution license (http://creativecommons.org/licenses/by/3.0/). 